\title{
Deposition of trace elements from high temperature gases of Satsuma-Iwojima volcano
}

\author{
F. Africano ${ }^{1}$, G. Van Rompaey ${ }^{1}$, A. Bernard ${ }^{1}$, and F. Le Guern ${ }^{2}$ \\ ${ }^{1}$ Geochemistry CP 160/02, University of Brussels, 50 Av. F. Roosevelt, 1050 Brussels, Belgium \\ ${ }^{2}$ CNRS, LSCE, Av. De la Terrasse, 91198 Gif/Yvette, France
}

(Received July 5, 2000; Revised September 25, 2001; Accepted September 28, 2001)

\begin{abstract}
The Satsuma-Iwojima volcano has been emitting continuously high temperature $\left(600^{\circ}\right.$ to $\left.900^{\circ} \mathrm{C}\right)$ gases for at least 800 years. We identified the minerals that form in response to closed-system cooling of these gases and from airmixing reactions. Major differences compared with the sublimates observed at other volcanoes are the occurrence of wulfenite $\left(\mathrm{PbMoO}_{4}\right)$ and several mixed chlorides. This is the first report of wulfenite in fumarolic deposits. Thermochemical modeling shows that wulfenite precipitates between $540^{\circ}$ and $490^{\circ} \mathrm{C}$ from a gas with lower sulfur content and/or higher $f \mathrm{O}_{2}$, and a higher Mo content $\left(\log f \mathrm{SO}_{2}=-2.1, \log f \mathrm{H}_{2} \mathrm{~S}=-5, \log f \mathrm{O}_{2}=-18.6\right.$, $\log f \mathrm{H}_{2} \mathrm{MoO}_{4}=-4.5, \mathrm{~T}=500^{\circ} \mathrm{C}$ ) than the previously reported gas composition. The occurrence of abundant $\mathrm{K}$, $\mathrm{Pb}, \mathrm{Fe}, \mathrm{Zn}, \mathrm{Rb}$ and $\mathrm{Cs}$ mixed chlorides may be promoted by the low $\mathrm{S} / \mathrm{Cl}$ of the Satsuma-Iwojima high temperature gases. Natural sublimates of metallic elements (molybdenite, wulfenite, anglesite, Tl-Pb and Tl-Bi sulfides, Mo oxydes and $\mathrm{Pb}$ oxides) are deposited along the fumarolic conduit and on the ground under conditions of variable temperatures and $f \mathrm{O}_{2}$. The increase in $f \mathrm{O}_{2}$ due to the mixing of the gases with the atmosphere reduces the volatility of several elements ( $\mathrm{As}, \mathrm{Sn}, \mathrm{Na}, \mathrm{K}$ and $\mathrm{Pb}$ ) by promoting their condensation at higher temperatures. As air mixes with volcanic gas in the fumarolic plume, we can expect to find these metals as aerosols.
\end{abstract}

\section{Introduction}

Volcanic emissions are one of the major natural sources of metal compounds in the atmosphere (Nriagu, 1989). Satsuma-Iwojima volcano is emitting continuously high temperature gases for over 800 years (Shinohara et al., 1993), acting as an important contributor to the atmospheric injection of metal compounds (Hedenquist, 1995). The flux of several metals ( $\mathrm{Fe}, \mathrm{Sn}, \mathrm{Mo}, \mathrm{Zn}$ and $\mathrm{Pb}$ ) to the atmosphere from the high temperature fumaroles of SatsumaIwojima volcano was estimated to range from 1 to $10 \mathrm{t} / \mathrm{yr}$ by Hedenquist et al. (1994).

The subject of this paper is to investigate the transport and deposition of trace elements such as $\mathrm{K}, \mathrm{Na}, \mathrm{Fe}, \mathrm{Cu}, \mathrm{Zn}$, As, $\mathrm{Rb}, \mathrm{Mo}, \mathrm{Cd}, \mathrm{Sn}, \mathrm{Cs}$ and $\mathrm{Pb}$, which concentrations in the high temperature volcanic gases $\left(600-900^{\circ} \mathrm{C}\right)$ range from $1 \mathrm{ppb}$ to $15 \mathrm{ppm}$. During their transport from the magma to the atmosphere, the volcanic gases cool leading to the precipitation of metal-bearing sublimates. Atmospheric $\mathrm{O}_{2}$ may enter into the fumarolic vent, mixing with the volcanic gases and contributing to the precipitation of oxidized solid phases. The term "sublimates" is used, in this paper, for the minerals which precipitate directly from the gas phase by vapor deposition processes, including those formed after gas-air mixing.

Le Guern and Bernard (1982) and Bernard (1985) developed a method of collecting sublimates that allows the study of metals deposition in high temperature gases without con-

Copy right (C) The Society of Geomagnetism and Earth, Planetary and Space Sciences (SGEPSS); The Seismological Society of Japan; The Volcanological Society of Japan; The Geodetic Society of Japan; The Japanese Society for Planetary Sciences. tamination by atmospheric $\mathrm{O}_{2}$ and reaction with wall rocks. The silica tubes are introduced into the fumarolic vent, allowing the gases to flow through the tube. Sublimation occurs along a temperature gradient and the minerals are separated according to their temperature of deposition. The deposits on the inner walls of the tubes are formed without air contamination and those on the outer walls are formed by the mixing of the gases with air. Analysis of sublimates collected by this method enable us to identify the form and the temperatures of emission of the trace elements to the atmosphere.

We used different approaches to study the transport and deposition of the trace elements: 1) the mineralogy of sublimates, collected using silica tubes, was analyzed by scanning electron microscope (SEM) and X-ray microdiffration; 2) the mineralogy of the natural sublimates collected from the rock surface was studied by the same methods; 3) we applied the computer code GASWORKS (Symonds et al., 1992; Symonds and Reed, 1993), on a system of 16 elements, to model the cooling of the gases and the precipitation of the solid phases during cooling.

\section{Sampling and Analytical Methods}

Silica tubes were inserted into three fumaroles at Iwodake crater floor in November 1997 (Fig. 1). Temperatures measured at the inlets of these tubes were $850^{\circ}, 760^{\circ}$ and $535^{\circ} \mathrm{C}$. We analyzed the deposits on both, the inner and the outer walls of the tubes. In the laboratory, the silica tubes were cut in sections of 6 to $8 \mathrm{~cm}$ and each section was split in several fractions. The small quantity of the deposited ma- 


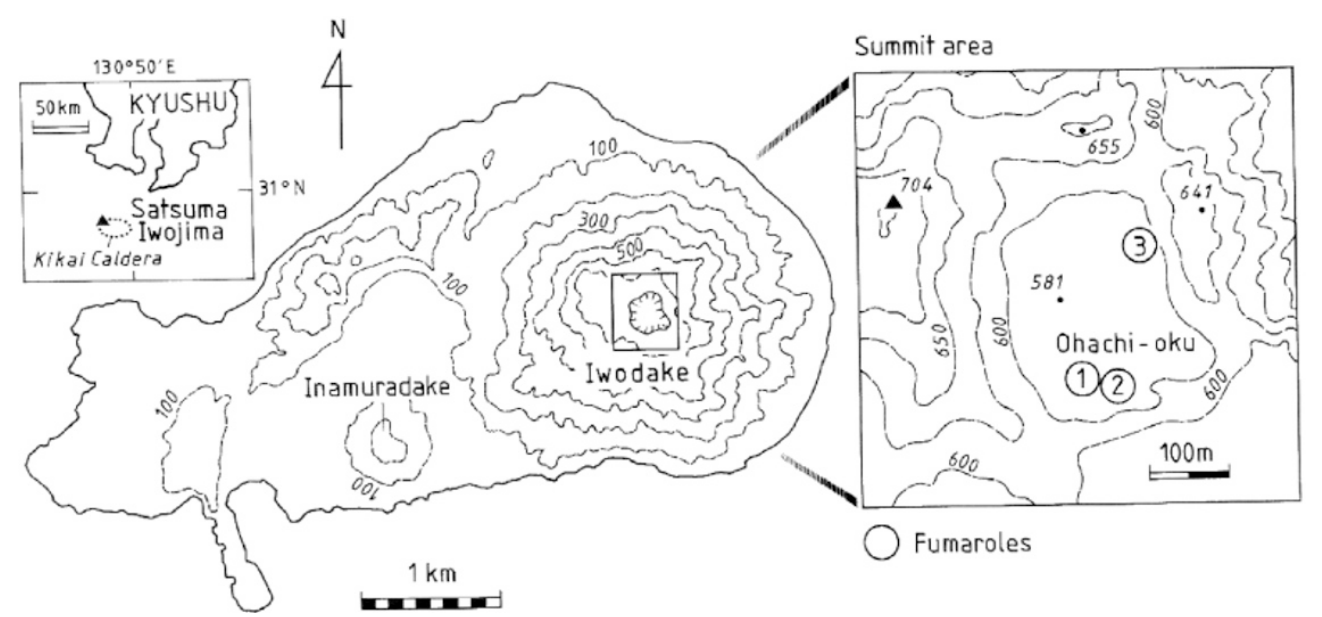

Fig. 1. Map of Satsuma-Iwojima volcano, Iwodake summit crater and location of the sampled high temperature fumaroles.

Tube 1

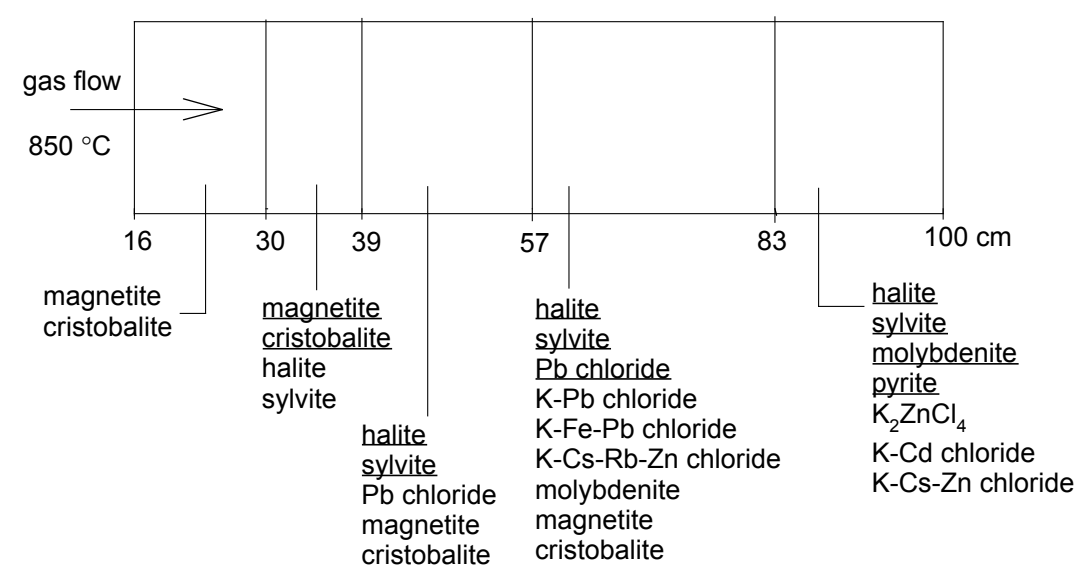

Fig. 2. Assemblages of sublimates precipitated on the inner walls of the silica tube 1. Major phases are underlined. The total amount of minor phases is $<10 \%$.

terial $\left(0.5-4.5 \mathrm{mg} / \mathrm{cm}^{2}\right)$ makes the mineralogical analysis a complex task. Silica tube fragments $\left(1 \mathrm{~cm}^{2}\right)$ were cut to analyze the deposits directly on the inner and on the outer walls of the tube by SEM and X-ray microdiffraction. The deposits on the tube walls were also scraped and dissolved in pure $\mathrm{H}_{2} \mathrm{O}$ in order to remove the $\mathrm{Na}, \mathrm{K}$ chlorides and make the identification of minor phases easier. One aliquot of these insoluble fractions was collected on $0.4 \mu \mathrm{m} \mathrm{Nu}$ clepore filters (Jedwab, 1975) to be analyzed by SEM and optical microscopy and the other aliquot was used for X-ray microdiffraction.

The sublimates, occuring in the walls of ground fissures, were sampled from a few centimeters depth. In the laboratory, we separated natural sublimates from the rock forming minerals based on their morphology. The sublimates are characterized by individual and well-formed crystals deposited on surfaces of fractures.

The sublimates were analyzed with a SEM, JEOL 733 with an energy dispersive X-ray spectrometer (EDS). The EDS detector was equipped with a high X-ray transmission efficiency NORVAR window, which enables detection of the low atomic number elements $(Z>3)$. Chemical composition of minerals was obtained by a standardless procedure using the ZAF matrix correction program. Analyses were carried out at $15 \mathrm{kV}$ and $3 \mathrm{nA}$.

A BRUKER X-ray microdiffractometer equipped with a new detector GADDS (General Area Detector Diffraction System) was also used to study sublimates mineralogy. Analyses were made at $40 \mathrm{kV}$ and $30 \mathrm{~mA}$ with a $\mathrm{Cu}-\mathrm{K} \alpha$ tube and a graphite monochromator. The GADDS detection system allows the acquisition of X-ray diffraction patterns on very small quantities of powdered materials $(5 \mathrm{mg})$. The $\mathrm{X}$-ray diffraction patterns were obtained with a $500 \mu \mathrm{m}$ collimator at a working distance of $20 \mathrm{~cm}$ and with a resolution of $0.02^{\circ} 2 \theta$.

\section{Mineralogy of the Sublimates \\ 3.1 Silica tubes deposits}

Mineral assemblages, separated according to their temperature of deposition, form strips of different colors and 
Tube 2

a

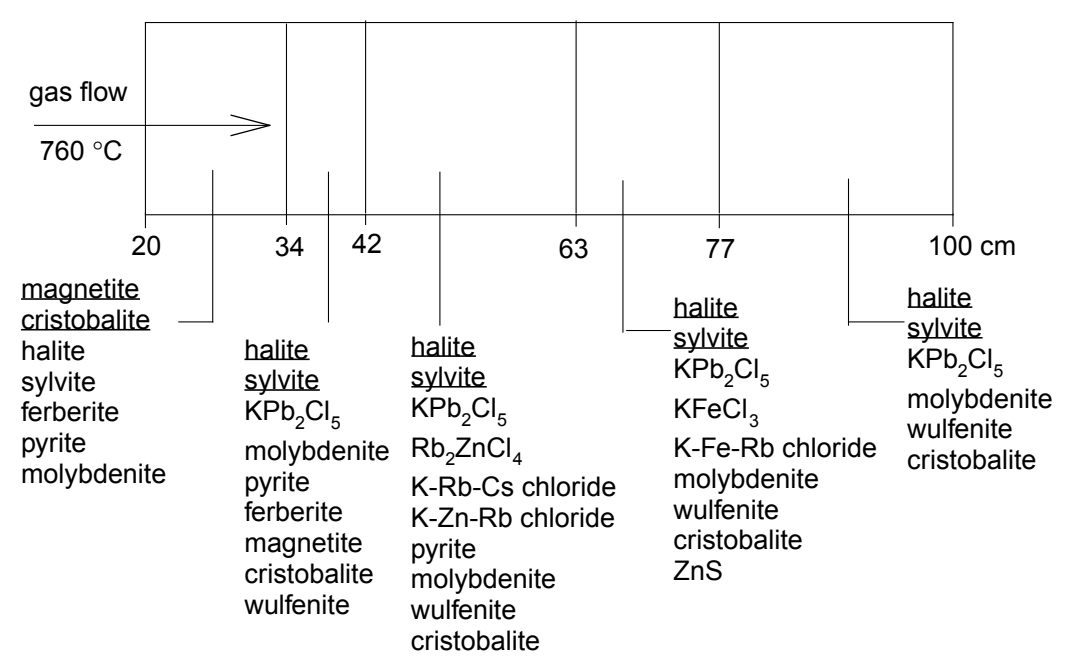

b

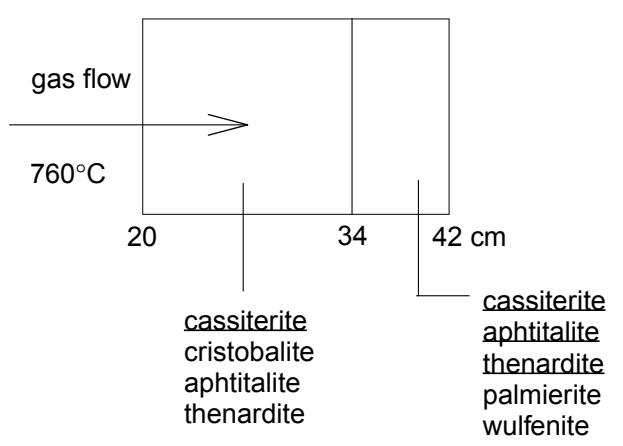

Fig. 3. Assemblages of sublimates precipitated on the walls of tube 2. a) inner walls; b) outer walls. Major phases are underlined. The total amount of minor phases is $<10 \%$.

widths along the tube walls. The temperature gradient changes along the tube. An important decrease in temperature occurs where the tube is cooled by the atmosphere. To describe the mineralogy of the deposits, we divided the tubes into several zones according to the identified mineral assemblages (Figs. 2, 3 and 4). The minerals identified by SEM and by XRD are presented in Table 1 .

\subsubsection{Tube 1 (temperature at the inlet $=850^{\circ} \mathrm{C}$ ) Inner walls}

A) $16-30 \mathrm{~cm}$

The deposits are essentially composed of a layer of cryptocristalline magnetite $\left(\mathrm{Fe}_{3} \mathrm{O}_{4}\right)$ under a layer of fibrous micron-size cristobalite $\left(\mathrm{SiO}_{2}\right)$ which is elongated in the same direction as the gas stream. Dispersed crystals of halite $(\mathrm{NaCl})$ and sylvite $(\mathrm{KCl})$ are also observed (Fig. 5(a)). Sylvite enriched in $\mathrm{Br}$ (2 to 6 wt.\%) also occurs in aggregates. Bromine is known to replace $\mathrm{Cl}$ in sylvite (Coradossi and Mazzi, 1985; Quisefit et al., 1989).

B) $30-39 \mathrm{~cm}$

Cristobalite and magnetite are the predominant phases but their morphology are different from that of the previous zone. Cristobalite occurs as spheres $(20-30 \mu \mathrm{m})$ and magnetite occurs as well-formed octahedrons $(20-30 \mu \mathrm{m})$. Epitaxial overgrowth of cristobalite and magnetite crystals is also observed (Fig. 5(b)). The large size and well-formed crystals suggest deposition from a slightly supersaturated gas.

C) $39-57 \mathrm{~cm}$

Halite and sylvite (Fig. 5(c)) are the dominant phases from here until the end of the tube. Sylvite enriched in $\mathrm{Rb}$ (0.5 wt.\%) occurs in aggregates. This zone is also marked by the occurrence of a $\mathrm{Pb}$ bearing chloride.

D) $57-83 \mathrm{~cm}$

This zone is distinguished by the precipitation of foliated molybdenite $\left(\mathrm{MoS}_{2}, 20-40 \mu \mathrm{m}\right)$ which becomes more abundant after $65 \mathrm{~cm}$. Magnetite and cristobalite are rare. The $\mathrm{Pb}$ chloride becomes more abundant. Peaks corresponding to cotunnite $\left(\mathrm{PbCl}_{2}\right)$ were identified in XRD patterns. Unidentified $\mathrm{K}-\mathrm{Pb}$ and $\mathrm{K}-\mathrm{Fe}-\mathrm{Pb}$ bearing chlorides are frequently observed. Unidentified K-Cs-Rb-Zn chloride which general formula calculated from SEM analyses is $\mathrm{K}_{2.1} \mathrm{Cs}_{0.3} \mathrm{Rb}_{0.9} \mathrm{Zn}_{1.3} \mathrm{Cl}_{6}$ is also present.

E) $83-100 \mathrm{~cm}$

Pyrite $\left(\mathrm{FeS}_{2}\right)$ coexists with rare magnetite in the first cen- 


\section{Tube 3}

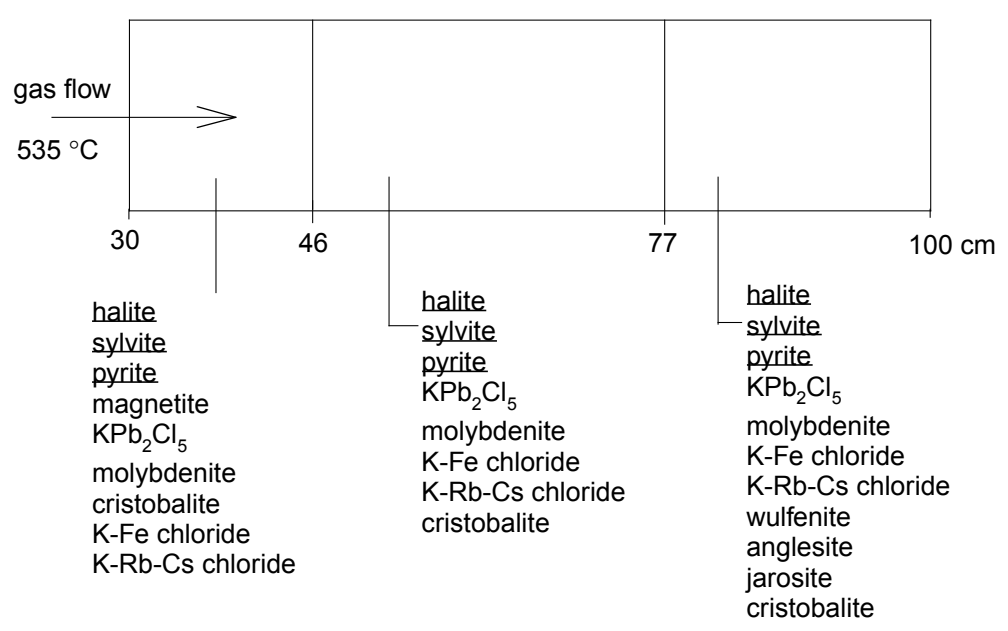

Fig. 4. Assemblages of sublimates precipitated on the inner walls of the silica tube 3 . Major phases are underlined. The total amount of the other phases is $<10 \%$.

Table 1. Minerals identified by XRD. The identification was confirmed by SEM and EDS.

\begin{tabular}{llc}
\hline \multicolumn{1}{c}{ Mineral name } & \multicolumn{1}{c}{$\mathrm{Chemical} \mathrm{formula}_{2}$} & PDF card number \\
\hline magnetite & $\mathrm{Fe}_{3} \mathrm{O}_{4}$ & $19-0629$ \\
cristobalite & $\mathrm{SiO}_{2}$ & $39-1425$ \\
sylite & $\mathrm{NaCl}$ & $05-0628$ \\
aphtitalite & $\mathrm{KCl}$ & $41-1476$ \\
thenardite & $\mathrm{K}_{3} \mathrm{Na}_{\left(\mathrm{SO}_{4}\right)_{2}}$ & $20-0928$ \\
molybdenite & $\mathrm{Na}_{2} \mathrm{SO}_{4}$ & $37-1465$ \\
pyrite & $\mathrm{MoS}_{2}$ & $37-1492$ \\
ferberite & $\mathrm{FeS}_{2}$ & $42-1340$ \\
wulfenite & $\mathrm{FeWO}_{4}$ & $46-1446$ \\
anglesite* & $\mathrm{PbMoO}_{4}$ & $44-1486$ \\
palmierite & $\mathrm{PbSO}_{4}$ & $36-1461$ \\
jarosite & $\mathrm{K}_{2} \mathrm{~Pb}_{\left(\mathrm{SO}_{4}\right)_{2}}$ & $29-1015$ \\
hydroniumjarosite & $\mathrm{KFe}_{3}\left(\mathrm{SO}_{4}\right)_{2}(\mathrm{OH})_{6}$ & $22-0827$ \\
cassiterite & $\left(\mathrm{H}_{3} \mathrm{O}\right) \mathrm{Fe}_{3}(\mathrm{SO})_{2}(\mathrm{OH})_{6}$ & $31-0650$ \\
cotunnite & $\mathrm{SnO}_{2}$ & $41-1445$ \\
synthetic & $\mathrm{PbCl}_{2}$ & $26-1150$ \\
synthetic & $\mathrm{Rb}_{2} \mathrm{ZnCl}_{4}$ & $30-1100$ \\
synthetic & $\mathrm{K}_{2} \mathrm{ZnCl}_{4}$ & $33-1060$ \\
synthetic & $\mathrm{KPb}_{2} \mathrm{Cl}_{5}$ & $27-1364$ \\
ilsemannite* & $\mathrm{KFeCl}_{3}$ & $27-0403$ \\
\hline
\end{tabular}

*only observed in natural sublimates.

PDF - Powder diffraction file database (JCPDS-International Center for Diffraction Data).

timeters of this zone and become abundant (Fig. 5(d)) at the end of the tube where pyrite and molybdenite compose the insoluble fraction of the deposits. Other $\mathrm{K}$ bearing chlorides replace those observed in the previous zone. Unidentified $\mathrm{K}-\mathrm{Cd}$ and $\mathrm{K}-\mathrm{Cs}-\mathrm{Zn}$ chlorides $\left(\mathrm{K}_{1.6} \mathrm{Cd}_{2.3} \mathrm{Cl}_{6}\right.$; $\mathrm{K}_{2.3} \mathrm{Cs}_{0.5} \mathrm{Zn}_{1.5} \mathrm{Cl}_{6}$ ) are present. A $\mathrm{K}-\mathrm{Zn}$ chloride is abundant with XRD patterns similar to $\mathrm{K}_{2} \mathrm{ZnCl}_{4}$.

\subsubsection{Tube 2 (temperature at the inlet $=760^{\circ} \mathrm{C}$ )} Inner walls

A) $20-34 \mathrm{~cm}$

The first deposits occur at $20 \mathrm{~cm}$ and are composed of small $(5 \mu \mathrm{m})$ octahedrons of magnetite and spherical aggre- 

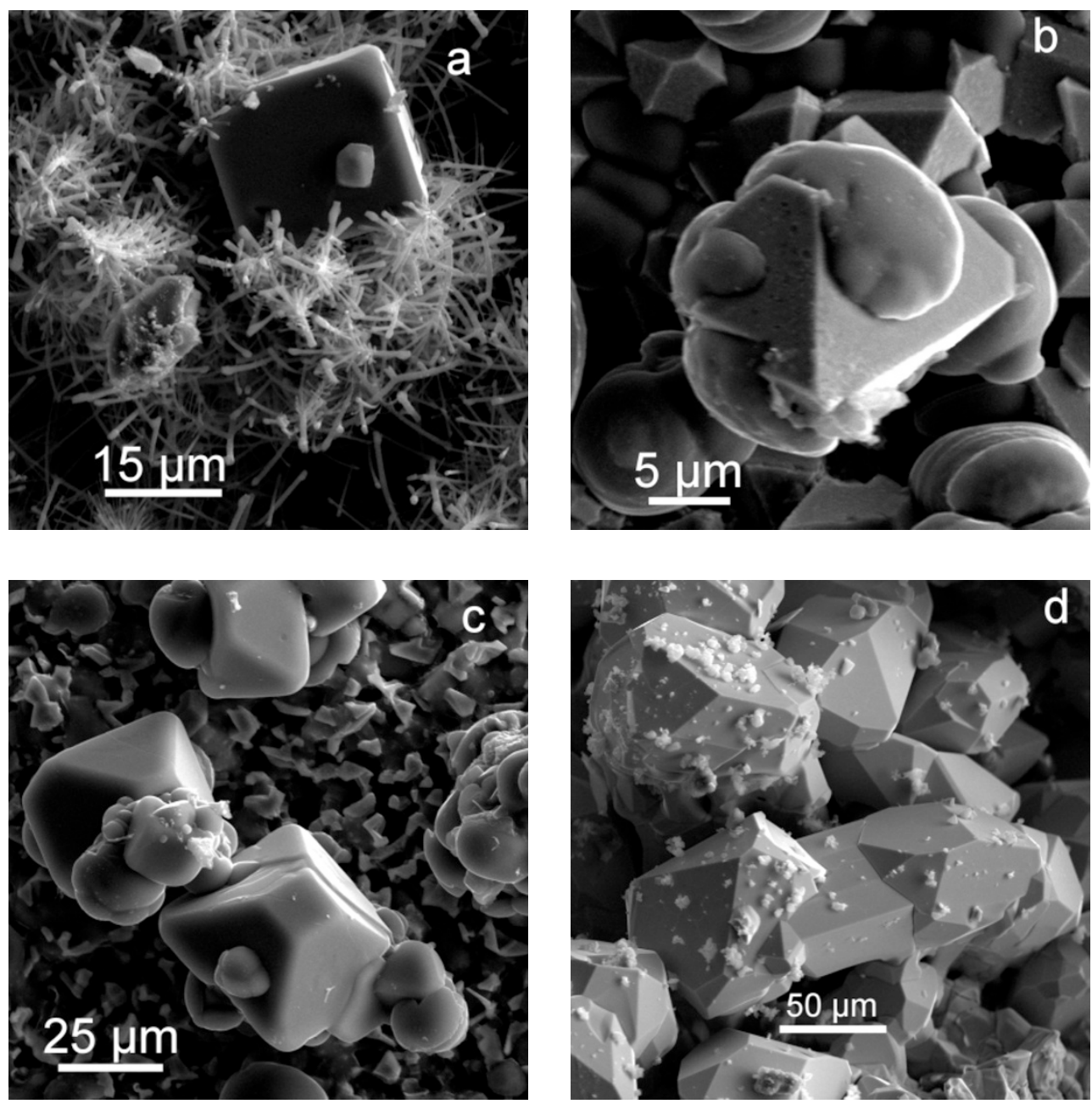

Fig. 5. SEM images of the sublimates inside tube 1. a) cubic crystals of halite mixed with cristobalite in section A; b) intergrow of magnetite and cristobalite crystals in section B; c) octahedrons of sylvite and spheres of cristobalite in section C; d) crystals of pyrite in section E.

gates $(10-15 \mu \mathrm{m})$ of small $(1 \mu \mathrm{m})$ crystals of cristobalite. Ferberite $\left(\mathrm{FeWO}_{4}\right)$ and pyrite are mixed with these oxides. Halite and sylvite are dispersed among the deposits. The halides become more abundant at the end of this zone where molybdenite precipitates. Figures 6(a) and (b) show the XRD patterns of the insoluble fraction and of the bulk deposit of this zone, respectively.

B) $34-42 \mathrm{~cm}$

The halides are the predominant phases till the end of the tube. This zone is distinguished by the precipitation of a $\mathrm{K}$ $\mathrm{Pb}$ chloride and wulfenite $\left(\mathrm{PbMoO}_{4},<5 \mu \mathrm{m}\right)$ which is only detected on the membrane filters (Fig. 7(a)). This is the first reported occurrence of wulfenite in fumarolic environment. Figures 6(c) and (d) show the XRD patterns of the insoluble fraction and of the bulk deposit of this zone, respectively.

C) $42-63 \mathrm{~cm}$

Ferberite and magnetite disappear in this zone. The K$\mathrm{Pb}$ chloride becomes more abundant and is present till the end of the tube (Fig. 7(b)). Patterns of XRD show the peaks of $\mathrm{KPb}_{2} \mathrm{Cl}_{5}$ (Fig. 6(d)) and $\mathrm{Rb}_{2} \mathrm{ZnCl}_{4}$ that have been synthetized in the laboratory but never found in nature. Aggregates $(60-80 \mu \mathrm{m})$ of tabular crystals of unidentified K$\mathrm{Rb}$-Cs chloride are observed. A K-Zn chloride enriched in
$\mathrm{Rb}$ occurs. Pyrite, molybdenite, wulfenite and cristobalite, compose the insoluble fraction with decreasing abundance.

D) $63-77 \mathrm{~cm}$

This zone is marked by the disappearance of pyrite. Iron is incorporated in $\mathrm{K}-\mathrm{Fe}$ chlorides. Peaks of $\mathrm{KFeCl}_{3}$ are identified in XRD patterns. A K-Fe chloride enriched in $\mathrm{Rb}$ (up to 4 wt.\%) also occurs. Some isolated crystals of $\mathrm{Zn}$ sulfide are observed. Molybdenite, wulfenite and cristobalite occur till the end of the tube.

E) $77-100 \mathrm{~cm}$

Difference with the previous zone is the absence of $\mathrm{Fe}$ bearing phases.

\section{Outer walls}

The deposits are observed between 20 and $42 \mathrm{~cm}$ and are composed by cristobalite, cassiterite $\left(\mathrm{SnO}_{2}\right)$, which is the predominant phase, aphtitalite $\left[\mathrm{K}_{3} \mathrm{Na}\left(\mathrm{SO}_{4}\right)_{2}\right]$, thenardite $\left(\mathrm{Na}_{2} \mathrm{SO}_{4}\right)$, palmierite $\left[\mathrm{K}_{2} \mathrm{~Pb}\left(\mathrm{SO}_{4}\right)_{2}\right]$ and wulfenite. Figures 8(a) and (b) show XRD patterns of the insoluble fraction and of the bulk deposit, respectively.

\subsubsection{Tube 3 (temperature at the inlet $=535^{\circ} \mathrm{C}$ )}

Inner walls

A) $30-46 \mathrm{~cm}$

First deposition occurs at $30 \mathrm{~cm}$ with prevalence of halite 


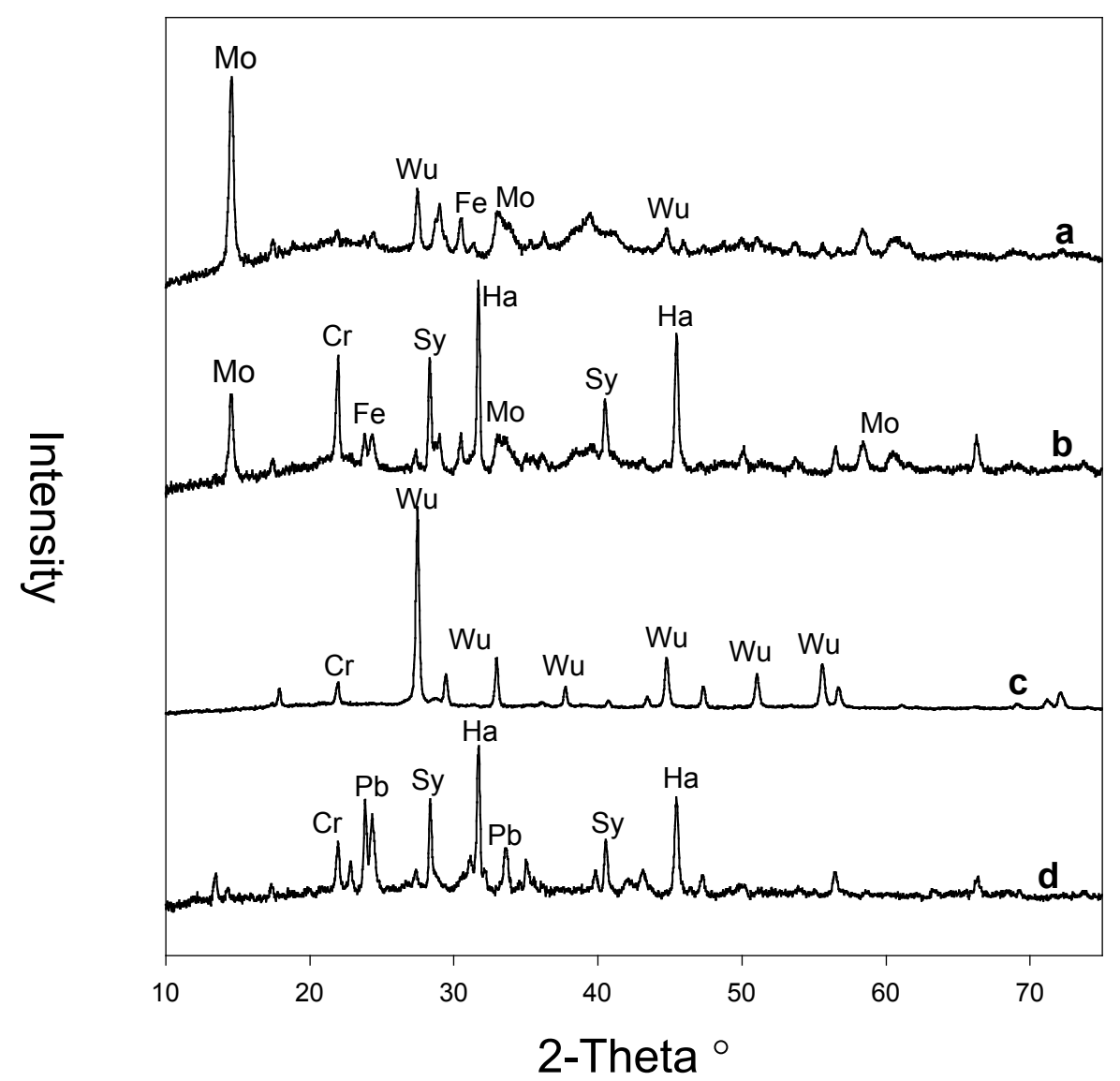

Fig. 6. X-ray microdiffraction patterns of selected samples. a) insoluble fraction from the section A of tube 2; b) bulk deposit from the inner walls of the section $\mathrm{A} ; \mathrm{c}$ ) insoluble fraction from the section $\mathrm{B}$ of tube $2 ; \mathrm{d}$ ) bulk fraction from the section $\mathrm{B}$. Mineral abbreviations: Cr $=$ cristobalite; $\mathrm{Fe}=$ ferberite; $\mathrm{Ha}=$ halite; $\mathrm{Mo}=$ molybdenite; $\mathrm{Pb}=$ synthetic $\mathrm{KPb}_{2} \mathrm{Cl}_{5} ; \mathrm{Sy}=$ sylvite; $\mathrm{Wu}=$ wulfenite.

and sylvite. Pyrite is also abundant and coexists with scarce magnetite. Patterns of XRD also show the peaks of $\mathrm{KPb}_{2} \mathrm{Cl}_{5}$, molybdenite and cristobalite. Other $\mathrm{K}$ bearing chlorides (K-Fe chloride, $\mathrm{K}-\mathrm{Rb}-\mathrm{Cs}$ chloride) are less frequently observed.

B) $46-77 \mathrm{~cm}$

The same minerals as in the previous zone occur with exception of magnetite. Cristobalite is also rarely observed.

C) $77-100 \mathrm{~cm}$

In this section of the tube, the same mineral assemblage as in the previous zone is associated with sulfates. Wulfenite, mixed with pyrite, is abundant. Dispersed and well-formed crystals $(100-150 \mu \mathrm{m})$ of anglesite $\left(\mathrm{PbSO}_{4}\right)$, jarosite $\left[\mathrm{KFe}_{3}\left(\mathrm{SO}_{4}\right)_{2}(\mathrm{OH})_{6}\right]$ and hydroniumjarosite $\left[\left(\mathrm{H}_{3} \mathrm{O}\right) \mathrm{Fe}_{3}\left(\mathrm{SO}_{4}\right)_{2}(\mathrm{OH})_{6}\right]$ occur on the surface of the deposit (Fig. 7(c)).

\subsection{Natural sublimates}

Minerals deposited on the ground surface are mainly molybdenite (Fig. 7(d)), wulfenite, anglesite, Pb oxide, sulfides of $\mathrm{Tl}-\mathrm{Pb}$ and $\mathrm{Tl}-\mathrm{Bi}$, and Mo oxide (XRD patterns show reflections similar to the hypothetical ilsemannite).

\section{Thermochemical Modeling}

We used the program GASWORKS (Symonds et al., 1992; Symonds and Reed, 1993) to model: 1) cooling of a high temperature gas of Satsuma-Iwojima fumaroles from $877^{\circ} \mathrm{C}$ down to $100^{\circ} \mathrm{C}$ and 2) mixing of the volcanic gas with air and simultaneous cooling. GASWORKS calculates heterogeneous chemical equilibrium among ideal gases, solids and liquids. The thermodynamic database GASTHERM includes more than 1000 gaseous species, solids and liquids for systems with up to 42 elements. We introduced data for wulfenite (Barin, 1993) as this mineral was abundant in tube 2 and was also observed in tube 3 . Wulfenite has never been reported in sublimate studies. Symonds et al. (1987) and Symonds and Reed (1993) discussed errors in thermochemical data for gaseous $\mathrm{PbCl}_{4}$ and $\mathrm{PbBr}_{4}$. As suggested by these authors, we suppressed $\mathrm{PbCl}_{4}$ and $\mathrm{PbBr}_{4}$ from the database. Lack of thermodynamic data for several phases observed in the tubes, such as $\mathrm{K}-\mathrm{Pb}-\mathrm{Zn}-\mathrm{Fe}$ bearing chlorides, is also a limitation of the model as well as the lack of data for $\mathrm{Tl}$, $\mathrm{Bi}, \mathrm{Cs}, \mathrm{Rb}, \mathrm{Br}$ and $\mathrm{Si}$ concentrations in the volcanic gases. Nevertheless, the modeling results should provide important insights into the natural sublimation process. Calculations were done at 1 bar pressure on a 16-element system $(\mathrm{H}-\mathrm{C}$ $\mathrm{O}-\mathrm{S}-\mathrm{Cl}-\mathrm{F}-\mathrm{N}-\mathrm{Na}-\mathrm{K}-\mathrm{Fe}-\mathrm{Zn}$-Pb-Mo-Cu-As-Sn). We used the chemical composition of the $877^{\circ} \mathrm{C}$ gas from Iwodake crater (Table 2) in the thermochemical calculations. This composition is similar to the parent gas estimated by Shinohara et al. (1993) after correction for $\mathrm{CO}_{2}$ content (Shinohara et al., 2002). We cooled the gas from $877^{\circ}$ to $100^{\circ} \mathrm{C}$ by $5^{\circ} \mathrm{C}$ steps. Calculations were done with and without fractionation of 

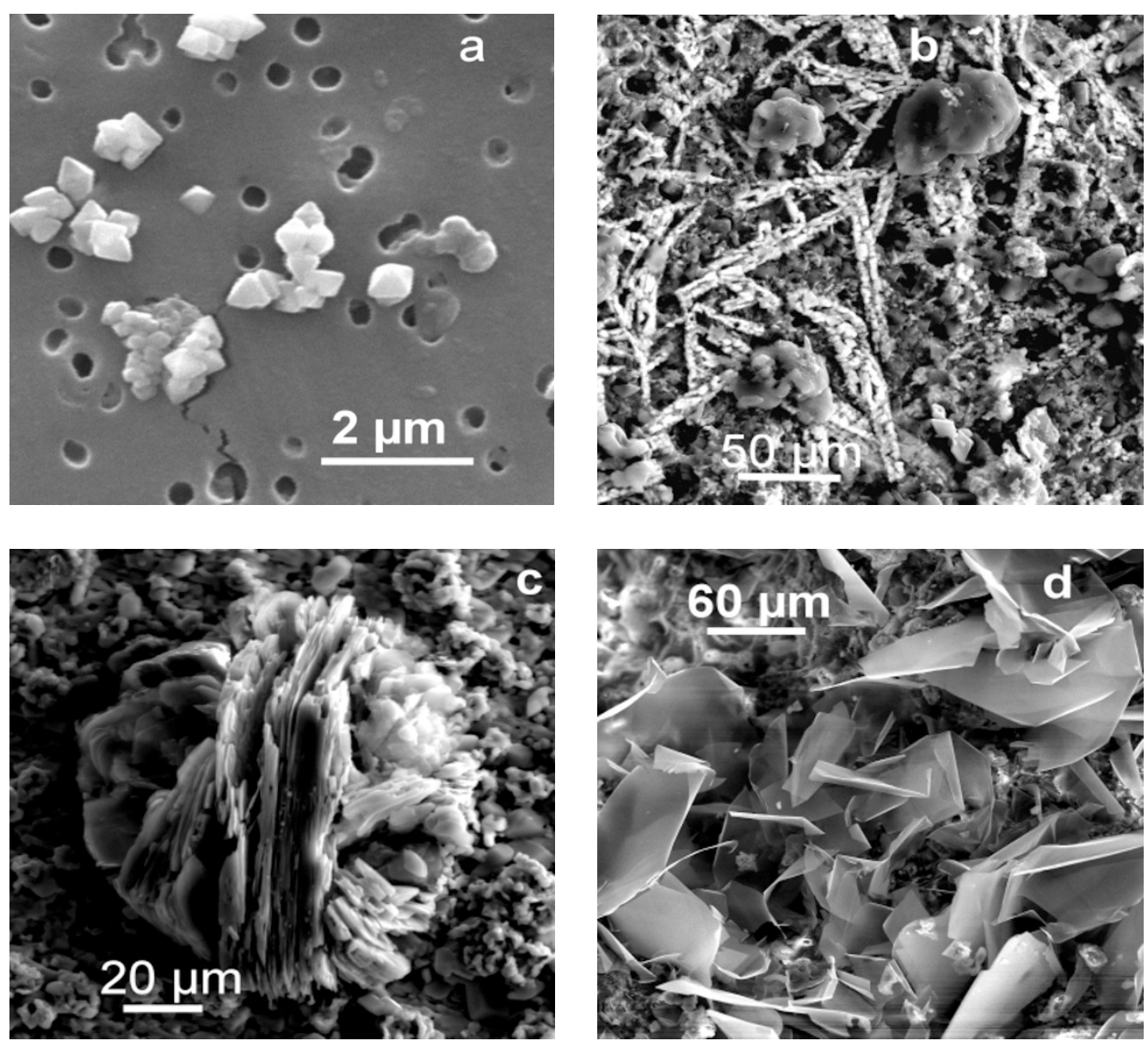

Fig. 7. SEM images of the sublimates. a) crystals of wulfenite inside section $\mathrm{B}$ of tube 2, collected on membrane filters; b) prismatic crystals of $\mathrm{KPb}_{2} \mathrm{Cl}_{5}$ inside section $\mathrm{C}$ of tube $2 ; \mathrm{c}$ ) jarosite crystals growing on top of the deposit inside section $\mathrm{C}$ of tube 3 ; d) foliated molybdenite in natural sublimates.

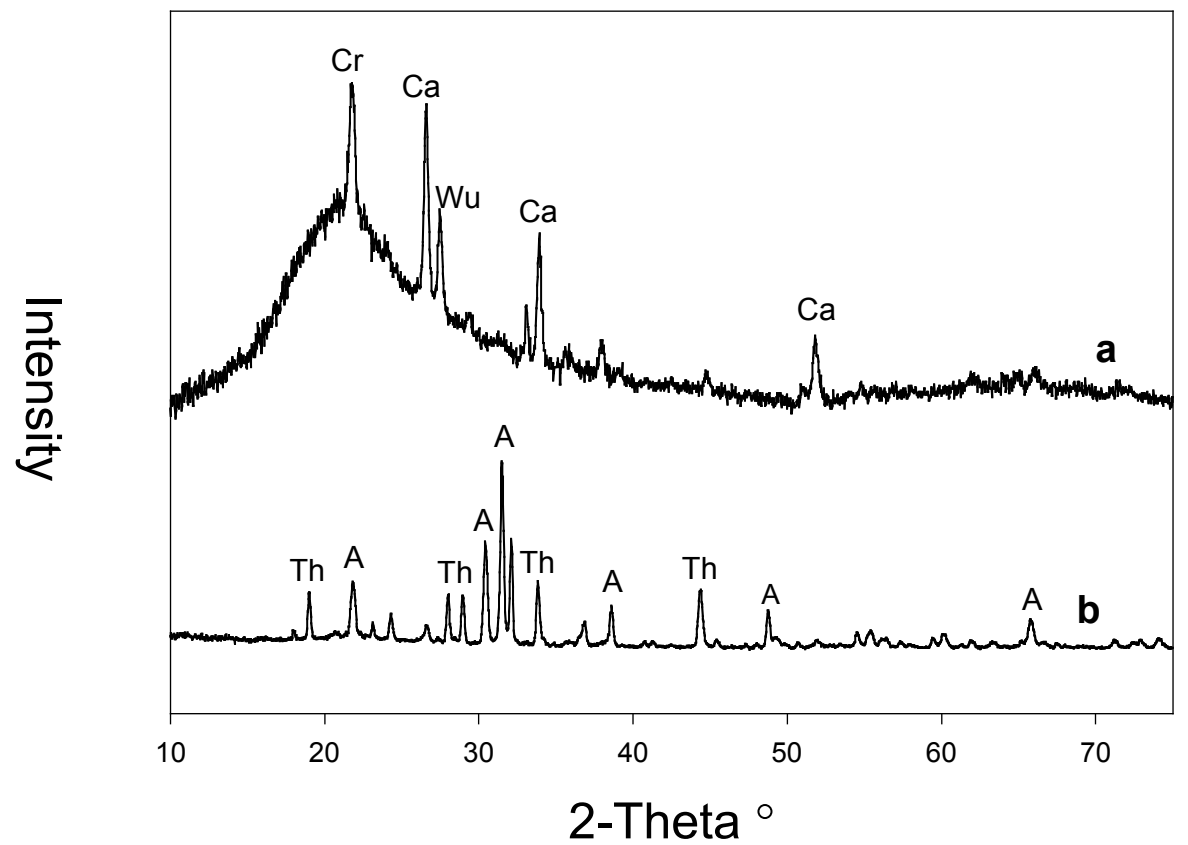

Fig. 8. X-ray microdiffraction patterns of the deposits on the outer walls of tube 2. a) insoluble fraction; b) bulk deposit. Mineral abbreviations: $\mathrm{A}=$ Aphthitalite $\mathrm{Ca}=$ cassiterite $\mathrm{Cr}=$ cristobalite; $\mathrm{Th}=$ thenardite; $\mathrm{Wu}=$ wulfenite. 
Table 2. Composition of high temperature fumarolic gases, Iwodake crater, Satsuma-Iwojima volcano (Shinohara et al., 1993; Hedenquist et al., 1994).

\begin{tabular}{|c|c|c|c|}
\hline $\mathrm{T}^{\circ} \mathrm{C}$ & 877 & 702 & 505 \\
\hline $\mathrm{H}_{2} \mathrm{O}$ & 97.5 & 97.61 & 96.63 \\
\hline $\mathrm{CO}_{2}$ & $0.316^{*}$ & 0.341 & 0.473 \\
\hline $\mathrm{St}$ & 0.983 & 1.121 & 1.058 \\
\hline $\mathrm{SO}_{2}$ & 0.918 & 0.971 & 0.882 \\
\hline $\mathrm{H}_{2} \mathrm{~S}$ & 0.066 & 0.149 & 0.176 \\
\hline $\mathrm{HCl}$ & 0.677 & 0.585 & 1.679 \\
\hline $\mathrm{HF}$ & 0.033 & 0.045 & 0.023 \\
\hline $\mathrm{H}_{2}$ & 0.474 & 0.268 & 0.132 \\
\hline $\mathrm{O}_{2}$ & $<0.001$ & - & $<0.001$ \\
\hline $\mathrm{N}_{2}$ & 0.008 & 0.032 & 0.008 \\
\hline $\mathrm{CH}_{4}$ & 0.0003 & - & - \\
\hline $\mathrm{CO}$ & 0.001 & 0.0004 & 0.0005 \\
\hline $\mathrm{S} / \mathrm{Cl}$ & 1.4 & 1.9 & 0.63 \\
\hline $\mathrm{C} / \mathrm{Cl}$ & 0.46 & 0.58 & 0.28 \\
\hline \multirow[t]{2}{*}{$\mathrm{C} / \mathrm{S}$} & 0.322 & 0.30 & 0.44 \\
\hline & ppm & & \\
\hline $\mathrm{Na}$ & 12 & 15 & 6.1 \\
\hline K & 2.10 & 4.8 & 1.2 \\
\hline $\mathrm{Fe}$ & 0.62 & 1.18 & 0.06 \\
\hline As & 1.74 & 3.27 & 4.55 \\
\hline $\mathrm{Pb}$ & 1.04 & 1.77 & 1.27 \\
\hline $\mathrm{Zn}$ & 0.15 & 0.24 & 0.06 \\
\hline $\mathrm{Cu}$ & 0.03 & 0.04 & 0.06 \\
\hline Mo & 0.43 & 0.16 & 0.03 \\
\hline $\mathrm{Sn}$ & 0.48 & 0.78 & 0.66 \\
\hline
\end{tabular}

Data for major species in mole $\%$.

${ }^{*} \mathrm{CO}_{2}$ values corrected (Shinohara et al., 2002).

solids and liquids. On calculations with fractionation, the amounts of solids and liquids reaching saturation were removed after each calculation step. We also evaluated the effect of atmospheric oxidation in the precipitation of the solid phases.

\subsection{Minerals precipitation during cooling}

As the temperature decreases, the metals in a gas phase supersaturate forming mineral assemblages. The calculations with fractionation show that the precipitation of a given phase occurs only in a relatively narrow range of temperature. For each temperature step, the calculated amounts of sublimates are plotted from $877^{\circ}$ to $100^{\circ} \mathrm{C}$ (Fig. 9). Small amounts of $\mathrm{Cu}_{2} \mathrm{~S}$ precipitate between $700^{\circ}$ and $300^{\circ} \mathrm{C}$. Magnetite is predominant till $650^{\circ} \mathrm{C}$. Halite is the most abundant phase between $650^{\circ}$ and $550^{\circ} \mathrm{C}$. Sylvite precipitates and becomes predominant at $550^{\circ} \mathrm{C}$. Molybdenite is the first sulfide stable $\left(\mathrm{T}=640^{\circ} \mathrm{C}\right)$. Precipitation of pyrite occurs from $510^{\circ}$ to $400^{\circ} \mathrm{C}$. Magnetite completely disappears at $500^{\circ} \mathrm{C}$. Cassiterite precipitates from $550^{\circ}$ to $240^{\circ} \mathrm{C}$. Sphalerite is observed from $400^{\circ}$ to $175^{\circ} \mathrm{C}$. Cotunnite occurs at temperatures below $325^{\circ} \mathrm{C}$. Liquid sulfur forms at $175^{\circ} \mathrm{C}$ and is
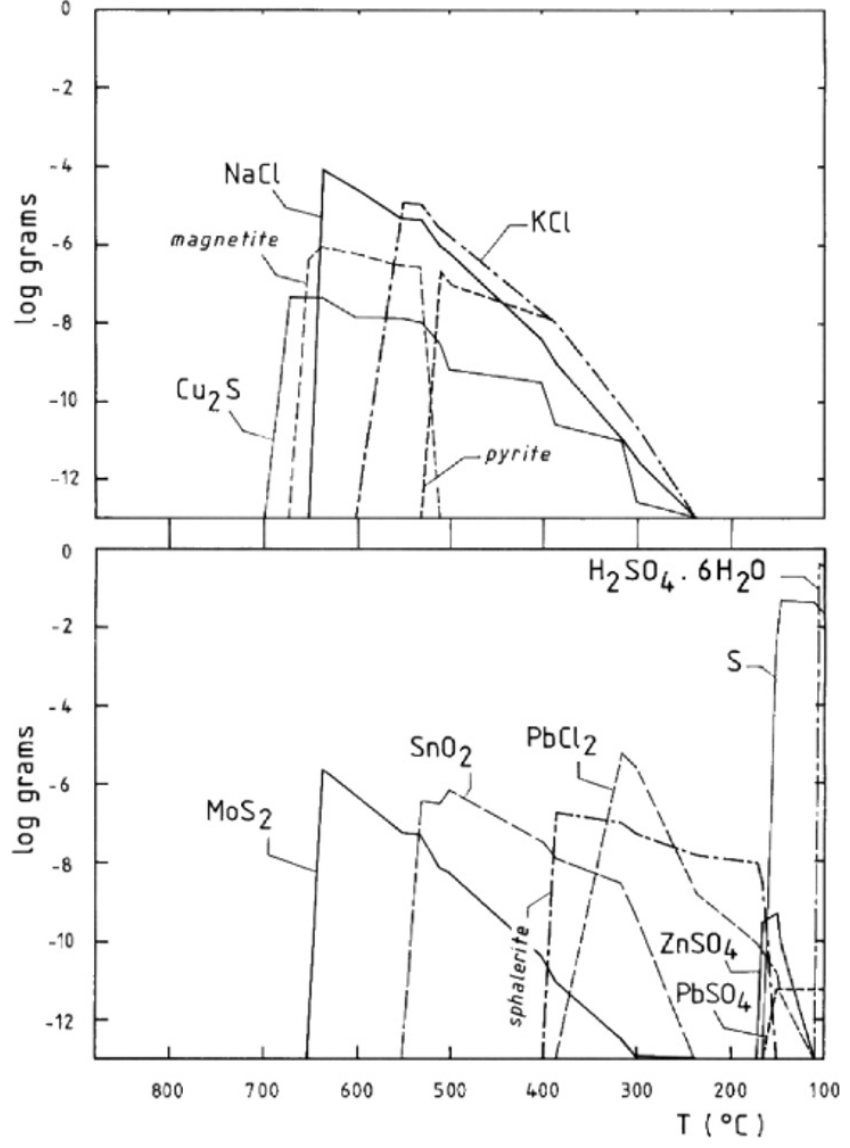

Fig. 9. Calculated amounts of solid phases precipitating during cooling of the $877^{\circ} \mathrm{C}$ gas. The calculations were done under an open system (with fractionation of solids and liquids), without air mixing.

replaced by monoclinic sulfur at $117^{\circ} \mathrm{C}$, and $\mathrm{H}_{2} \mathrm{SO}_{4} \cdot 6 \mathrm{H}_{2} \mathrm{O}$ forms at $105^{\circ} \mathrm{C}$.

Calculations in the closed system (without fractionation) show the same mineral assemblages within the same temperature ranges with the exception that sulfates $\left(\mathrm{Na}_{2} \mathrm{SO}_{4}\right.$, $\mathrm{K}_{2} \mathrm{SO}_{4}, \mathrm{Fe}_{2}\left(\mathrm{SO}_{4}\right)_{3}, \mathrm{ZnSO}_{4}$ and $\left.\mathrm{PbSO}_{4}\right)$ replace halides and sulfides at low temperatures $\left(\mathrm{T}<175^{\circ} \mathrm{C}\right)$.

\subsection{Mixing with air and cooling}

We added, in a stepwise manner, small amounts of air $\left(22 \% \mathrm{O}_{2}\right.$ and $\left.78 \% \mathrm{~N}_{2}\right)$ to the $877^{\circ} \mathrm{C}$ gas. Temperature of the mixing air was fixed at $25^{\circ} \mathrm{C}$, and the program calculates the temperature of the gas + air mixture at each calculation step. The temperature is calculated as a linear function of the mixture composition, assuming that heat capacities of the volcanic gas and the air are the same (Symonds and Reed, 1993). Temperature decreases from $877^{\circ}\left(\log f \mathrm{O}_{2}=\right.$ $-12.1)$ to $100^{\circ} \mathrm{C}\left(\log f \mathrm{O}_{2}=-0.7\right)$ by addition of 10 moles of air to 1 mole of volcanic gas (Fig. 10(a)). Figure 10(b) shows the mineral assemblages deposited during cooling of the mixture. Hematite precipitates from $850^{\circ}$ to $550^{\circ} \mathrm{C}$ and is replaced by $\mathrm{Fe}_{2}\left(\mathrm{SO}_{4}\right)_{3}$ below $550^{\circ} \mathrm{C}$. Cassiterite occurs between $850^{\circ}$ and $620^{\circ} \mathrm{C}$. Sodium and potassium sulfates are the most abundant phases in this range of temperature. Between $620^{\circ}$ and $520^{\circ} \mathrm{C}, \mathrm{PbSO}_{4}$ is also abundant. Arsenic oxide occurs at temperatures below $600^{\circ} \mathrm{C}$. Zinc sulfate precipitates at $520^{\circ} \mathrm{C}$. At temperatures below $300^{\circ} \mathrm{C}, \mathrm{MoO}_{3}$ 

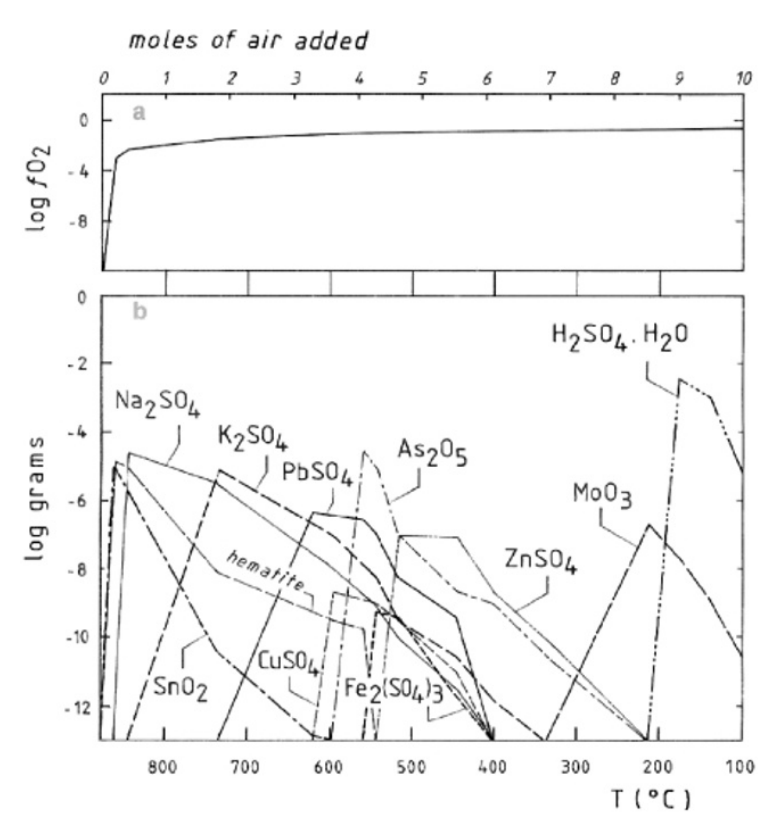

Fig. 10. Thermochemical calculations of gas $\left(877^{\circ} \mathrm{C}\right)+\operatorname{air}\left(25^{\circ} \mathrm{C}\right)$ mixture. The calculations were done under an open system (with fractionation). a) Variation of $f \mathrm{O}_{2}$ with the amount of air added. Temperature of the mixture decreases according to the mixed amount of air. b) Calculated amounts of solid phases during cooling of the gas + air mixture.

become stable. Hygroscopic sulfuric acid forms at $175^{\circ} \mathrm{C}$.

\section{Discussion}

Before their emission into the atmosphere, a fractionation of the metals from the gas phase occurs by deposition of sublimates along the fumarole conduits. These sublimates, formed under an environment free of air contamination, are typically those observed inside the silica tubes. A fraction of the metals is deposited at the fumarole vents, where atmospheric $\mathrm{O}_{2}$ may enter. Comparison of the natural sublimates with the results of the thermochemical modeling shows that these minerals were deposited at variable temperature and $f \mathrm{O}_{2}$ conditions corresponding to different degrees of gas-air mixing. Another fraction of the metals is injected into the atmosphere and condenses in the fumarolic plume as aerosols. These solid phases, formed by the mixing of the gases with the atmosphere, correspond to those observed on the outer walls of the silica tubes.

The mineral assemblages calculated in both thermochemical models of cooling of the high temperature gas and cooling of the gas + air mixture show good agreement with those observed in the inner and the outer walls of the silica tubes. These comparisons allow to constrain the $\mathrm{fO}_{2}$ conditions and the temperatures of the mineral deposition (Figs. 11(a) and (b)). We assume, in these calculations, an internal equilibrium during the cooling of the gas phase. The prevalence of well-formed crystals in the high temperature zones of the tubes, typical of a slow growing, suggests that they are formed in conditions close to equilibrium. It is also important to note that the rate of oxidation occurring on the outer walls of the tubes seems to be very fast since all the phases observed are typically formed under high $f \mathrm{O}_{2}$ conditions.

The majority of the sublimates observed in the silica

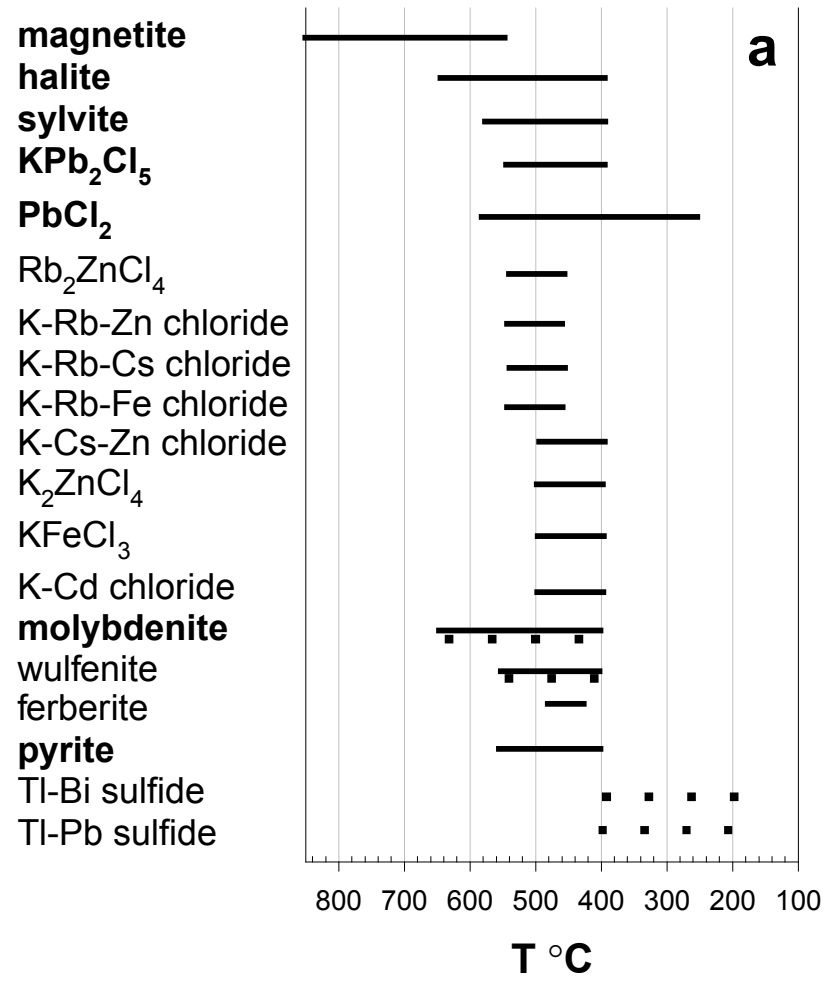

cassiterite
aphtitalite
thenardite
palmierite
hematite
wulfenite
anglesite
$\mathrm{Pb}$ oxide
Mo oxide

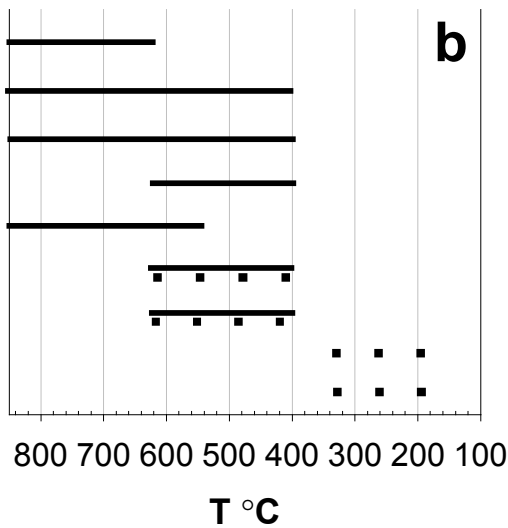

Fig. 11. Estimated temperature ranges of sublimate deposition. a) Low $f \mathrm{O}_{2}$ conditions $\left(\log =-12.6\right.$ at $850^{\circ} \mathrm{C}$ to -28.3 at $\left.300^{\circ} \mathrm{C}\right)$. b) $\mathrm{High}$ $f \mathrm{O}_{2}$ conditions $\left(\log =-2.5\right.$ at $850^{\circ} \mathrm{C}$ to -8.4 at $\left.300^{\circ} \mathrm{C}\right)$. The temperatures are estimated on the basis of the thermochemical calculations and/or mineral association in the silica tubes. Solid lines show sublimates observed in the tubes and dotted lines show natural sublimates. Major mineral phases are shown in bold.

tubes are similar with those observed at high temperature fumaroles on other volcanoes situated at subduction zones. Deposition of magnetite at high temperatures $\left(\mathrm{T}>600^{\circ} \mathrm{C}\right)$, chlorides at temperatures ranging from $650^{\circ}$ to $300^{\circ} \mathrm{C}$, molybdenite from $650^{\circ}$ to $500^{\circ} \mathrm{C}$, ferberite from $600^{\circ}$ to $500^{\circ} \mathrm{C}$, pyrite from $600^{\circ}$ to $300^{\circ} \mathrm{C}$ are typically reported in high temperature fumaroles with low $\mathrm{fO}_{2}$ (Bernard, 1985; Symonds et al., 1987; Quisefit et al., 1989). Sulfates are frequently observed inside tubes collected at highly oxidized fumaroles (Bernard, 1985; Taran et al., 2000) or in natural sublimates (Stoiber and Rose, 1974; Naughton et al., 1974; Oskarsson, 1981). 
Minerals of highly volatile elements like As, Tl, Se or $\mathrm{Sb}$ typically observed in low temperatures $\left(\mathrm{T}<300^{\circ} \mathrm{C}\right)$ deposits and in volcanic aerosols (Bernard, 1985; Crowe et al., 1987; Gauthier, 1998) are not observed in the silica tubes analyzed in this study. Temperatures in the tubes studied might be too high to deposit these elements. The calculations show that under high $f \mathrm{O}_{2}\left(\log f \mathrm{O}_{2}=-1.2\right)$ conditions, As condenses at high temperatures $\left(600^{\circ} \mathrm{C}\right)$ as $\mathrm{As}_{2} \mathrm{O}_{5}$. Thallium, which is probably one of the most volatile metals (Gauthier, 1998) is incorporated in $\mathrm{Pb}$ and Bi sulfides in natural sublimates.

Wulfenite observed in tubes 2 and 3 and in natural sublimates has never been reported in fumarolic deposits. In low $f \mathrm{O}_{2}$ conditions, the $\mathrm{Pb}$-bearing solid phases formed are usually galena, $\mathrm{Pb}$-Bi bearing sulfides (Stoiber and Rose, 1974; Bernard, 1985; Symonds et al., 1987; Quisefit et al., 1989) and Pb-bearing chlorides (Symonds et al., 1987; Symonds, 1993; Wahrenberger, 1997). Molybdenum condenses as molybdenite (Stoiber and Rose, 1974; Bernard and Le Guern, 1986; Bernard et al., 1990). In high $\mathrm{fO}_{2}$ conditions, the $\mathrm{Pb}$ sublimates deposited are anglesite (Taran et al., 2000) and palmierite and, at low temperatures, $\mathrm{Pb}$ and Mo oxides (Stoiber and Rose, 1974). Wulfenite coexists with halite, sylvite, pyrite and molybdenite in tube 2 . Thermochemical modeling shows that this mineral assemblage occurs between $550^{\circ}$ and $400^{\circ} \mathrm{C}$ (Fig. 9). Molybdenum content reported for the Satsuma-Iwojima gases (0.4$1.7 \mathrm{mg} / \mathrm{kg}$; Hedenquist et al., 1994) is similar to those measured in other volcanoes situated at subduction zones. Figure 12 shows the stability of wulfenite, molybdenite and galena, anglesite, and cotunnite with respect to the fugacities of $\mathrm{O}_{2}$ and $\mathrm{S}_{2}$ at $500^{\circ} \mathrm{C}$. The stability of thenardite and halite is also shown because these phases occur on the outer walls and on the inner walls of the tubes respectively. Compositions of the gases from Satsuma-Iwojima, Merapi and Kudryavy volcanoes, fall in the stability field of molybdenite and halite as observed in tube 1 (Fig. 2). Wulfenite coexists with molybdenite in tube 2 and could be de-

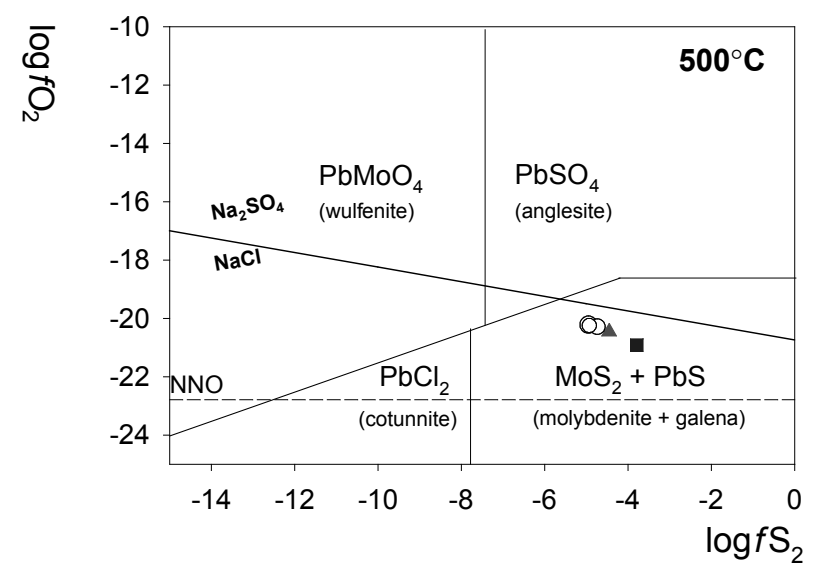

Fig. 12. Relative stability of wulfenite, anglesite, cotunnite, molybdenite and galena with respect to $f \mathrm{O}_{2}$ and $f \mathrm{~S}_{2}$. The equilibrium gas compositions were calculated at $500^{\circ} \mathrm{C}$ with GASWORKS: circles $=$ Satsuma-Iwojima gases, triangle $=$ Kudryavy, 1995 (Fischer et al., 1998), square = Merapi, 1979 (Bernard, 1985). For reference, the $\mathrm{Ni} / \mathrm{NiO}$ oxygen buffer (NNO) line is also shown by a dashed line. posited from a gas with lower $f \mathrm{~S}_{2}$ and/or with a slightly higher $f \mathrm{O}_{2}$ than those calculated for the Satsuma-Iwojima gases. We searched the conditions of wulfenite precipitation with GASWORKS by changing $\mathrm{H}_{2} \mathrm{~S}, \mathrm{O}_{2}$ and Mo content in the gas. First we cooled the $877^{\circ} \mathrm{C}$ gas to $500^{\circ} \mathrm{C}$ $\left(\log f \mathrm{O}_{2}=-20.2 ; \log f \mathrm{SO}_{2}=-2.1 ; \log f \mathrm{H}_{2} \mathrm{~S}=-2.6\right.$; $\left.\log f \mathrm{~S}_{2}=-4.9 ; \log f \mathrm{H}_{2} \mathrm{MoO}_{4}=-7.5\right)$. A minimum saturation index for wulfenite $(\log \mathrm{Q} / \mathrm{K}=-0.6)$ is obtained by subtracting $0.2 \mathrm{~mol} \%$ of $\mathrm{H}_{2} \mathrm{~S}$ and adding $0.05 \mathrm{~mol} \%$ of $\mathrm{O}_{2}$. Wulfenite precipitates by addition of $0.1 \mathrm{~mol} \%$ of Mo to this gas $\left(\log f \mathrm{O}_{2}=-18.6 ; \log f \mathrm{SO}_{2}=-2.1\right.$; $\left.\log f \mathrm{H}_{2} \mathrm{~S}=-5 ; \log f \mathrm{~S}_{2}=-8.2 ; \log f \mathrm{H}_{2} \mathrm{MoO}_{4}=-4.5\right)$, in association with halite, sylvite and molybdenite. The theoretical cooling and heating of this hypothetical $500^{\circ} \mathrm{C}$ gas show that wulfenite precipitates between $540^{\circ}$ and $490^{\circ} \mathrm{C}$. These results suggest that the precipitation of wulfenite occurs from a gas with high Mo content. The formation of wulfenite at Satsuma-Iwojima implies that the Mo content of the gases is higher than that reported by Hedenquist et al. (1994) and probably higher than those measured at other volcanoes. The abundant Mo bearing minerals in the natural sublimates at Satsuma-Iwojima fumaroles also support this hypothesis.

Lead, Zn, Fe bearing chlorides and mixed K, Cs, Rb, Pb and $\mathrm{Zn}$ chlorides have been observed in silica tubes at other sites (Symonds et al., 1987; Symonds, 1993; Wahrenberger, 1997). These chlorides are also abundant in the tubes of Satsuma-Iwojima. Symonds (1993) observed abundant $\mathrm{PbKCl}_{3}$ at temperatures as high as $500^{\circ} \mathrm{C}$. Thermochemical calculations with the composition of Merapi high temperature gases show precipitation of galena at $\mathrm{T}<400^{\circ} \mathrm{C}$ replaced by $\mathrm{PbCl}_{2}$ at lower temperatures (Symonds et al., 1987). In the calculation model of the Satsuma-Iwojima gases, the precipitation of galena does not occur which is in agreement with the observations, but $\mathrm{PbCl}_{2}$ precipitates at temperatures $\left(350^{\circ} \mathrm{C}\right)$ lower than those of the $\mathrm{Pb}$ chlorides occurrence in the tubes. The $\mathrm{K}, \mathrm{Pb}$ and $\mathrm{Zn}$ contents of the gases are similar to those measured at the other sites. The low $\mathrm{S} / \mathrm{Cl}$ (0.6 to 1.9$)$ of the Satsuma-Iwojima gases explain the stability of the chlorides instead of the sulfides. The incorporation of $\mathrm{Rb}$ and $\mathrm{Cs}$ in $\mathrm{K}$ chlorides, and preferential incorporation of Cs favored by decreasing temperature, were also observed at other sites (Quisefit et al., 1989). Compositional variation of the alkali halides with decreasing temperatures $(\mathrm{NaCl}>\mathrm{KCl}>\mathrm{Rb}-\mathrm{Cs}$ bearing chlorides $>\mathrm{Cs}$ bearing chlorides) was previously discussed by Symonds and Reed (1993) and agrees with the decreasing volatility within the alkali family $(\mathrm{Cs}>\mathrm{Rb}>\mathrm{K}>\mathrm{Na}$ ) observed in aerosols (Hinkley et al., 1994; Gauthier, 1998). The calculations show that $\mathrm{Na}$ and $\mathrm{K}$ precipitate as halides below $650^{\circ} \mathrm{C}$ in reduced conditions but condense as sulfates at temperatures as high as $850^{\circ} \mathrm{C}$ from the oxidized gaseous mixture. In silica tubes, $\mathrm{Sn}$ is commonly incorporated in $\mathrm{Pb}-\mathrm{Bi}$ bearing sulfides deposited at temperatures lower than $450^{\circ} \mathrm{C}$ (Bernard, 1985; Symonds et al., 1987). In the SatsumaIwojima tubes, $\mathrm{Sn}$ is observed as cassiterite at temperatures from $760^{\circ} \mathrm{C}$ (temperature of the inlet of the tube 2) to approximately $600^{\circ} \mathrm{C}$ (minimal calculated temperature of deposition $=620^{\circ} \mathrm{C}$ ) only when the gas mixes with air $\left(\log f \mathrm{O}_{2}=-1.5\right)$. The highly oxidized gases of Colima 
volcano also deposited cassiterite at temperatures ranging from $550^{\circ}$ to $800^{\circ} \mathrm{C}$ (Taran et al., 2000). High $f \mathrm{O}_{2}$ favors the precipitation at higher temperatures of some elements (As, $\mathrm{Sn}, \mathrm{Na}, \mathrm{K}$ and $\mathrm{Pb}$ ). As air mixes with volcanic gas in the fumarolic plume, we can expect to find these metals as aerosols. The gas-particle conversion may occur in the plume depending on the temperature of the fumarolic emissions.

The occurrence of sulfates at the end of tube 3 suggests that secondary processes occurred after the deposition of the minerals. The larger size of the jarosite crystals and their euhedral morphology suggests that they did not precipitate directly from the supersaturated gaseous phase as the other solid phases. If the gas mixes with air which is allowed to enter in the tube at the extremity, the high $f \mathrm{O}_{2}$ will result in the formation of hygroscopic $\mathrm{H}_{2} \mathrm{SO}_{4}$ droplets at low temperatures $\left(175^{\circ}\right.$ C; Fig. 10; Symonds et al., 1992). The well developed crystals of anglesite and jarosite may be formed by reaction of $\mathrm{H}_{2} \mathrm{SO}_{4}$ with pyrite and $\mathrm{K}_{2} \mathrm{PbCl}_{5}$. Cristobalite is observed inside the Satsuma-Iwojima tubes. The formation of this phase in tubes was discussed previously (Bernard, 1985; Symonds et al., 1992) and is due to a volatilization of silica from the tube walls, followed by reprecipitation at lower temperatures.

\section{Concluding Remarks}

The results of this study bring information on the temperature and redox conditions at which the gas-to-particle conversion of metals may occur in the Satsuma-Iwojima fumarolic plume. The comparison between the thermochemical models and the mineralogical studies of the silica tubes show general agreement and also, suggests that higher $f \mathrm{O}_{2}$ due to the mixing of the gases with air during their injection into the atmosphere reduces significantly the volatility of several trace elements. Arsenic, a highly volatile element which is reported to condense at low temperatures $\left(\mathrm{T}<250^{\circ} \mathrm{C}\right)$ without gas-air mixing, condenses at around $600^{\circ} \mathrm{C}$ as $\mathrm{As}_{2} \mathrm{O}_{5}$ when the gas reacts with air. Tin starts to condense around $850^{\circ} \mathrm{C}$ as cassiterite, $300^{\circ} \mathrm{C}$ higher than expected without gas-air mixing. Sodium and $\mathrm{K}$ which are known to precipitate as halides below $650^{\circ} \mathrm{C}$, condense as sulfates at temperatures as high as $850^{\circ} \mathrm{C}$ from the oxidized gaseous mixture. Lead is deposited as chloride $\left(\mathrm{T}<550^{\circ} \mathrm{C}\right)$ without gas-air mixing and precipitates as sulfate at $620^{\circ} \mathrm{C}$ in oxidized conditions. Molybdenum, behaves differently from the other metals and precipitates as sulfide at higher temperatures $\left(650^{\circ} \mathrm{C}\right)$ in reduced conditions but as wulfenite $\left(f \mathrm{O}_{2}=-18.6, \mathrm{~T}=500^{\circ} \mathrm{C}\right)$ under slightly oxidized conditions. When the gas reacts with air, Mo condenses at $300^{\circ} \mathrm{C}$ as oxide. The formation of wulfenite in silica tubes and on the ground suggests a loss of sulfur from the high temperature gas and/or a slightly higher $f \mathrm{O}_{2}$ than the parent gas. The occurrence of wulfenite also implies that the Mo content of this fumarolic gas should be higher than the previously reported Mo content in the Satsuma-Iwojima gases. The volatility of $\mathrm{Fe}$ does not seem to be affected by the $f \mathrm{O}_{2}$ changes. This metal condenses at temperatures as high as $800^{\circ} \mathrm{C}$ as magnetite or hematite at low and high $f \mathrm{O}_{2}$ conditions, respectively. The low $\mathrm{S} / \mathrm{Cl}$ of the Satsuma high temperature gases explain the large abundance of the mixed chlorides observed. Furthermore, the decreasing temperatures of deposition of the alkali halides $(\mathrm{NaCl}>\mathrm{KCl}>\mathrm{Rb}$ Cs-bearing chlorides $>$ Cs-bearing chlorides) confirms that, within the alkali family, volatility increases with atomic number (Symonds and Reed, 1993; Hinkley et al., 1994; Gauthier, 1998).

The form in which the trace metals occur in the aerosols will control their behavior in the atmosphere, time of residence, solubility in clouds and final removal in rain or by dry deposition. Previous aerosol studies identified some of the metal bearing phases (Cadle et al., 1979; Rose et al., 1982; Hobbs et al., 1982; Mackinnon et al., 1984; Varekamp et al., 1986; Symonds and Reed, 1993; Toutain et al., 1995; Galindo et al., 1998) but could not provide information on the temperatures or conditions of the aerosols formation. Other solid phases probably present in the plumes might not be identified in the collected aerosols because of their low concentration or because of the small size of the particles $(<1 \mu \mathrm{m})$. The silica tube method is actually the only way to obtain these data for the volcanic emissions.

\section{References}

Barin, I., F. Sauert, and F. Hampson, Thermochemical data of pure substances, 921 pp., VCH, Weinheim, 1993.

Bernard, A., Les mécanismes de condensation des gaz volcaniques (chimie, minéralogie et équilibres des phases condensées majeures et mineures), Thèse de doctorat, Université Libre de Bruxelles, 1985.

Bernard, A. and F. Le Guern, Condensation of volatile elements in high temperature gases of Mt. St. Helens, J. Volcanol. Geotherm. Res., 28, 91-105, 1986

Bernard, A., R. Symonds, and W. Rose, Jr., Volatile transport and deposition of Mo, W and Re in high temperature magmatic fluids, Appl. Geochem., 5, 317-326, 1990.

Cadle, R. D., A. L. Lazrus, B. J. Huebert, L. E. Heidt, W. I. Rose, Jr., D. C. Woods, R. L. Chuan, R. E. Stoiber, D. B. Smith, and R. A. Zielinski, Atmospheric implications of studies of Central American volcanic eruption clouds, J. Geophys. Res., 84, 6961-6968, 1979.

Coradossi, N. and F. Mazzi, Variazione della constante reticolare $\mathrm{a}_{\mathrm{o}}$ con il contenuto di bromo nel chloruro di ammonio naturale (salmiak) di Vulcano (Isole Eolie), Rend. Soc. Ital. Min. petr., 40, 267-275, 1985.

Crowe, B., D. Finnegan, W. Zoller, and W. Boynton, Trace element geochemistry of volcanic gases and particles from 1983-1984 eruptive episodes of Kilauea Volcano, J. Geophys. Res., 92, 13708-13714, 1987.

Fischer, T., W. Giggenbach, Y. Sano, and S. Williams, Fluxes and sources of volatiles discharged from Kudryavy, a subduction zone volcano, Kurile Islands, Earth Planet. Sci. Lett., 160, 81-96, 1998.

Galindo, I., L. Ivlev, A. González, and R. Ayala, Airborne measurements of particle and gas emissions from the December 1994-January 1995 eruption of Popocatépetl volcano (Mexico), J. Volcanol. Geotherm. Res., 83, 197-217, 1998

Gauthier, P. J., Nucléides de courtes périodes dans les gaz et les magmas: Contribution à l'Etude du dégazage et de la dynamique des reservoirs magmatiques, Thèse de doctorat, Université Blaise Pascale, ClermontFerrand, 1998.

Hedenquist, J. W., The ascent of magmatic fluid: discharge versus mineralization, in Magmas, Fluids and Ore Deposits: Mineralogical Association of Canada, Short Course, edited by J. F. H. Thompson, 23, 263-289, 1995.

Hedenquist, J. W., M. Aoki, and H. Shinohara, Flux of volatiles and oreforming metals from the magmatic-hydrothermal system of Satsuma Iwojima volcano, Geology, 22, 585-588, 1994.

Hinkley, T. K., M.-F. Le Cloarec, and G. Lambert, Fractionation of families of major, minor, and trace metals across the melt-vapor interface in volcanic exhalations, Geochim. Cosmochim. Acta, 58, 3255-3263, 1994.

Hobbs, P., J. Tuell, D. Hegg, L. Radke, and M. Eltgroth, Particles and gases in the emissions from the 1980-1981 volcanic eruptions of Mt. St. Helens, J. Geophys. Res., 87, 11062-11086, 1982.

Jedwab, J., A method of extraction and analysis of possible cosmic particles from manganese nodules, Meteorics, 10, 233-240, 1975.

Le Guern, F. and A. Bernard, A new method for sampling and analyzing 
volcanic sublimates. Application to Merapi Volcano, Java, J. Volcanol. Geotherm. Res., 12, 133-146, 1982.

Mackinnon, I., J. Gooding, D. McKay, and U. Clanton, The El Chichón stratospheric cloud: solid particulates and settling rates, J. Volcanol. Geotherm. Res., 23, 125-145, 1984.

Naughton, J., V. Lewis, D. Hammond, and D. Nishimoto, The chemistry of sublimates collected directly from lava fountains at Kilauea Volcano, Hawaii, Geochim. Cosmochim. Acta, 38, 1679-1690, 1974.

Nriagu, J. O., A global assessment of natural sources of atmospheric trace metals, Nature, 338, 47-49, 1989.

Oskarsson, N., The chemistry of Icelandic lava incrustations and the latest stages of degassing, J. Volcanol. Geotherm. Res., 10, 93-111, 1981.

Quisefit, J. P., J. P. Toutain, G. Bergametti, M. Javoy, B. Cheynet, and A. Person, Evolution versus cooling of gaseous volcanic emissions from Momotombo Volcano, Nicaragua: Thermochemical model and observations, Geochim. Cosmochim. Acta, 53, 2591-2608, 1989.

Rose, W. I., R. L. Chuan, and D. C. Woods, Small particles in plumes of Mount St. Helens, J. Geophys. Res., 87, 4956-4962, 1982.

Shinohara, H., W. F. Giggenbach, K. Kazahaya, and J. W. Hedenquist, Geochemistry of volcanic gases and hot springs of Satsuma-Iwojima, Japan: Following Matsuo, Geochem. J., 27, 271-285, 1993.

Shinohara, H., K. Kazahaya, G. Saito, N. Matsushima, and Y. Kawanabe, Degassing activity from Iwodake rhyolitic cone, Satsuma-Iwojima volcano, Japan: Formation of a new degassing vent, 1990-1999, Earth Planets Space, 54, this issue, 175-185, 2002.

Stoiber, R. E. and W. I. Rose, Jr., Fumarole incrustations at active Central American volcanoes, Geochim. Cosmochim. Acta, 38, 495-516, 1974.

Symonds, R. B., Scanning electron microscope observations of sublimates from Merapi volcano, Indonesia, Geochem. J., 26, 341-354, 1993.
Symonds, R. B. and M. H. Reed, Calculation of multicomponent chemical equilibria in gas-solid-liquid systems: calculation methods, thermochemical data, and applications to studies of high-temperature volcanic gases with examples from Mount St. Helens, Amer. J. Sci., 293, 758-864, 1993.

Symonds, R. B., W. I. Rose, M. H. Reed, F. E. Lichte, and D. L. Finnegan, Volatilization, transport and sublimation of metallic and non-metallic elements in high temperature gases at Merapi Volcano, Indonesia, Geochim. Cosmochim. Acta, 51, 2083-2101, 1987.

Symonds, R. B., M. H. Reed, and W. I. Rose, Origin, specification, and fluxes of trace-element gases at Augustine volcano, Alaska: insights into magma degassing and fumarolic processes, Geochim. Cosmochim. Acta, 56, 633-657, 1992.

Taran, Y. A., A. Bernard, J. C. Gavilanes, and F. Africano, Native gold in mineral precipitates from high-temperature volcanic gases of Colima volcano, Mexico, Appl. Geochem., 15, 337-346, 2000.

Toutain, J. P., J. P. Quisefit, P. Briole, P. Aloupogiannis, P. Blanc, and G. Robaye, Mineralogy and chemistry of solid aerosols emitted from Mount Etna, Geochem. J., 29, 163-173, 1995.

Varekamp, J. C., E. Thomas, M. Germani, and P. R. Buseck, Particle geochemistry of volcanic plumes of Etna and Mount St. Helens, J. Geophys. Res., 91, 12233-12248, 1986.

Wahrenberger, C. M., Some aspects of the chemistry of volcanic gases, Dissertation for the degree of Doctor of Natural Science, Swiss Federal Institute of Technology, Zurich, 1997.

F. Africano (e-mail: fafrican@ulb.ac.be), G. Van Rompaey, A. Bernard, and F. Le Guern 